\title{
CLOUD COMPUTING: TEORI DAN IMPLEMENTASINYA DALAM DUNIA BISNIS DAN PEMASARAN
}

\author{
Sudaryono ${ }^{1}$ \\ Diah Aryani ${ }^{2}$ \\ Ira Tyas Ningrum ${ }^{3}$ \\ e-mail : Sudaryono2@yahoo.com,diah_4r@yahoo.com,ira_tyas@pribadiraharja.com
}

Diterima : 30 November 2011 / Disetujui : 7 Desember 2011

\begin{abstract}
Cloud computing is a technology that utilizes the internet services using a central server with the goal of maintaining a virtual nature of data and applications. The presence of cloud computing will obviously lead to changes in the workings of information technology systems within an organization. This is because the concepts of cloud computing through virtualization, standardization and other fundamental features can reduce information technology costs, simplify the management of information technology services, and accelerating service delivery. In general, cloud computing architecture consists of: (1) Infrastructure as a Service (IaaS), (2) Platform as a Service (PaaS), and (3) Software as a Service (SaaS). Characteristics of cloud computing are: (1) self-service (on demand self service), (2) broadband access (broadband access network), (3) clustered resource (resource pooling), (4) elastic (rapid elasticity), and (5) measured service (measured service). While the advantages of cloud computing is: (1) without any initial investment, (2) convert CAPEX into OPEX, (3) flexible and easily developed, (4) focus on the business, rather than information technology, and (5) of control and responsibility of service. With cloud computing consumers free themselves from the responsibility for managing the stack of computing resources. Levels ranging from SaaS when it is completely free, PaaS while still must make an application, and IaaS are still busy with the operating system. This contrasts with On-Premise to take care of all your own.
\end{abstract}

Keyword: Cloud computing, infrastructure, platform, software, information technology.

1. Dosen Jurusan Sistem Komputer, STMIK Raharja

Jl. jend Sudirman No. 40 Modern Cikokol-Tangerang Telp. 5529692

2. Dosen Jurusan Sistem Komputer, STMIK Raharja

J1. Jend Sudirman No. 40 Modern Cikokol-Tangerang Telp. 5529692

3. Mahasiswa Jurusan Sistem Informasi, STMIK Raharja

Jl. Jend Sudirman No. 40 Modern Cikokol-Tangerang Telp. 5529692

Vol.5 No.2 - Januari 2012 
Cloud computing atau komputasi awan ialah teknologi yang memanfaatkan layanan internet menggunakan pusat server yang bersifat virtual dengan tujuan pemeliharaan data dan aplikasi. Keberadaan komputasi awan jelas akan menimbulkan perubahan dalam cara kerja sistem teknologi informasi dalam sebuah organisasi. Hal ini karena komputasi awan melalui konsep virtualisasi, standarisasi dan fitur mendasar lainnya dapat mengurangi biaya teknologi informasi, menyederhanakan pengelolaan layanan teknologi informasi, dan mempercepat penghantaran layanan. Secara umum arsitektur komputasi awan terdiri dari: (1) Infrastructure as a Service (IaaS); (2) Platform as a Service (PaaS); dan (3) Software as a Service (SaaS). Karakteristik cloud computing adalah: (1) swalayan (on demand self service); (2) akses pita lebar (broadband network access); (3) sumberdaya terkelompok (resource pooling); (4) elastis (rapid elasticity); dan (5) layanan yang terukur (measured service). Sedangkan yang menjadi kelebihan cloud computing adalah: (1) tanpa investasi awal; (2) mengubah CAPEX menjadi OPEX; (3) lentur dan mudah dikembangkan; (4) fokus pada bisnis, bukan teknologi informasi; dan (5) kendali dan tanggungjawab pelayanan. Dengan cloud computing konsumen membebaskan diri dari tanggung jawab untuk mengelola stack sumber daya komputasi. Levelnya mulai dari SaaS ketika benar-benar bebas, PaaS ketika masih harus membuat aplikasi, dan IaaS yang masih sibuk dengan operating system. Ini berbeda dengan On-Premise yang harus mengurus semua sendiri.

Kata Kunci: Cloud computing, infrastructure, platform, software, teknologi informasi.

\section{PENDAHULUAN}

Penggunaan teknologi internet di dunia semakin meningkat. Setiap orang pasti telah menikmati layanan internet. Dahulu internet hanya digunakan oleh para pekerja di bidang teknologi komputasi berbasis internet dan yang mengerti teknologi itu saja. Seiring dengan perkembangan zaman, teknologi ini juga mengalami perkembangan kearah pencapaian kemudahan dan kenyamanan luar biasa dalam melakukan kegiatan sehari-hari yang dianggap tidak mungkin dapat dikerjakan dalam waktu singkat. Pengembangan teknologi komputasi berbasis internet sekarang ini lebih diarahkan kepada proses pengaplikasian sistem yang mudah dan tidak memerlukan banyak waktu atau tenaga (Turban, 2005). Permasalahan diperoleh dalam pengolahan sistem jaringan.Apabila ada suatu perubahan pada program aplikasi internet pada server dalam jaringan lokal, datanya harus diinstal ulang atau disesuaikan kembali, termasuk pada pemakaian komputer biasa, yang biasanya diperlukan sistem operasi dan program aplikasi.

Sistem operasi sangat menentukan program aplikasi. Kalau pemakai memilih sistem operasi MS Windows misalnya, maka aplikasinya pun harus berbasis Windows. Demikian juga kalau sistemnya berbasis DOS, Linux, Mac, dan 
sebagainya. Padahal memilih sistem operasi sendiri sering membuat pengguna merasa bingung. Sistem teknologi informasi yang ada sekarang ini sangat terbatasi oleh ruang. Ruang untuk server yang dibutuhkan untuk penyimpanan data dan peningkatan kemampuan perangkat keras dalam rangka peningkatan proses komputasi sangat terbatas dan memerlukan biaya yang tidak murah untuk menambah perangkat yang baru (Okuhara, 2010).

Sekarang konsep teknologi informasi cloud computing sedang hangat dibicarakan. Disadari atau tidak komputasi awan akan secara dramatis mengubah dunia bisnis dan industri teknologi informasi seperti yang dikenal sekarang. Istilah cloud computing mulai banyak didengar dan perkembangannya sangat luar biasa. Disebut-sebut teknologi cloud computing dapat menghilangkan permasalahan yang dijelaskan diatas. Perusahaan-perusahaan besar di bidang IT pun sekarang mencurahkan perhatiannya ke sana. Perusahaan-perusahaan akan dengan cepat beralih ke server-server awan karena lebih cost-efficient, artinya tidak perlu membeli server dan software yang mahal, implementasi yang kemungkinan gagalnya mencapai 55\% sampai dengan $75 \%$, mempekerjakan tenaga IT untuk maintenance, khawatir terhadap pembajakan hak kekayaan intelektual, dan lain-lain.

Daripada repot, perusahaan tinggal mengalihkan semua operasi IT-nya ke awan sehingga lebih fokus ke bisnis. Apa implikasinya? Sarjana-sarjana IT bisa menambah deretan pengangguran intelektual jika mereka tidak cepat beradaptasi. Teknologi baru selalu membawa perubahan, kesempatan, serta ancaman. Internet merubah segalanya, menghasilkan banyak milyarder muda, tetapi juga meruntuhkan banyak perusahaan raksasa (Lim, 2011). Era cloud computing telah hadir dan lulusan sarjana IT terancam tidak mendapat pekerjaan jika tidak dibenahi sistem pendidikan IT yang ada sekarang ini.

Apa sebenarnya cloud computing itu? Komputasi awan merupakan istilah bagi dunia teknologi informasi yang sistemnya hanya disewa. Maksudnya, dalam menerapkan teknologi ini,pelanggan diharuskan untuk menyewa beberapa komponen kerja di teknologi informasi, seperti server penyimpanan data hingga data center. Melihat perkembangan ini, maka dapat diprediksi standard teknologi di masa mendatang akan menjadi lebih sederhana karena ketersediaan dari banyak cloud service. Seluruh nama besar seperti IBM, Microsoft, Google, dan Apple, saat ini sedang terlibat dalam peperangan untuk menjadi penguasa terbesar terhadap teknologi awan ini. Oleh karena itu yang menjadi rumusan masalah dalam artikel ini adalah: (1) apa itu cloud computing?; (2) apa kelebihan dari teknologi cloud computing?; (3) layanan (service) apa saja yang ditawarkan oleh cloud computing?; dan (4) perusahaan mana saja yang sudah menyediakan jasa cloud computing dan bagaimana pelayanan yang diberikan terhadap client? Sedangkan yang menjadi tujuan penulisan 
artikel ini adalah: (1) mampu menjelaskan definisi dari cloud computing; (2) mampu memaparkan kelebihan yang ada pada teknologi cloud computing; (3) memberikan penjelasan mengenai layanan-layanan yang disediakan oleh cloud computing; dan (4) memberikan informasi mengenai perusahaan penyedia jasa cloud computing dan cara kerja pelayanannya terhadap client atau konsumen.

\section{PEMBAHASAN}

\section{Definisi Cloud Computing}

Cloud computing pada dasarnya adalah menggunakan internet-based service untuk men-support business process. Kata-kata "Cloud” sendiri merujuk kepada simbol awan yang di dunia teknologi informasi digunakan untuk menggambarkan jaringan internet (internet cloud). Cloud computing adalah gabungan pemanfaatan teknologi komputer ('komputasi') dan pengembangan berbasis internet ('awan'). Cloud/awan merupakan metafora dari internet, sebagaimana awan yang sering digambarkan pada diagram jaringan komputer, awan (cloud) dalam cloud computing juga merupakan abstraksi dari infrastruktur kompleks yang disembunyikan adalah suatu moda komputasi dimana kapabilitas terkait teknologi informasi disajikan sebagai suatu layanan (as a service), sehingga pengguna dapat mengaksesnya melalui internet ("di dalam awan") tanpa pengetahuan tentangnya, ahli dengannya, atau memiliki kendali terhadap infrastruktur teknologi yang membantunya.

Menurut jurnal yang dipublikasikan IEEE, Internet computing / cloud computing adalah suatu paradigma dimana informasi secara permanen tersimpan di server internet dan tersimpan secara sementara di komputer pengguna (client) termasuk di dalamnya adalah desktop, komputer tablet, notebook, sensor-sensor, monitor dan lain-lain. Cloud computing secara sederhana adalah "layanan teknologi informasi yang bisa dimanfaatkan atau diakses oleh pelanggannya melalui jaringan internet". Komputasi awan adalah suatu konsep umum yang mencakup SaaS, Web 2.0, dan tren teknologi terbaru lain yang dikenal luas, dengan tema umum berupa ketergantungan terhadap internet untuk memberikan kebutuhan komputasi pengguna. Sebagai contoh, Google Apps menyediakan aplikasi bisnis umum secara sharing yang diakses melalui suatu penjelajah web dengan perangkat lunak dan data yang tersimpan di server. Agar lebih mudah membayangkannya, dapat diilustrasikan pada gambar 1 berikut (Ercana, 2010). 


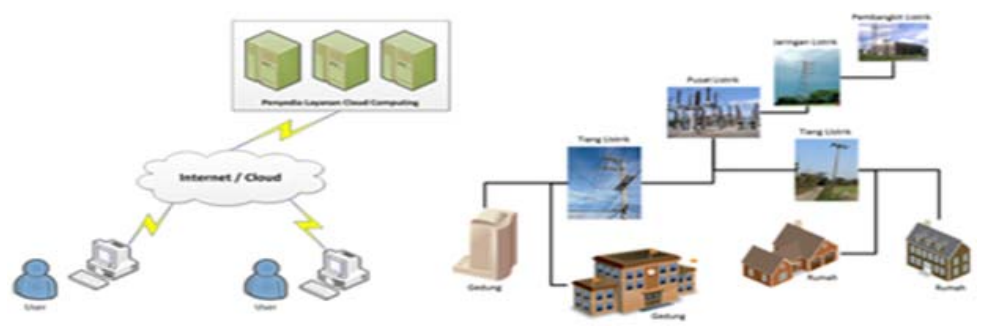

Gambar.1. Ilustrasi Could Computing

Sebagai ilustrasi, cloud computing dapat dibayangkan seperti sebuah jaringan listrik. Apabila membutuhkan listrik, apakah harus mempunyai pembangkit listrik sendiri? Tentu tidak. Tinggal menghubungi penyedia layanan (dalam hal ini,PLN), menyambungkan rumah dengan jaringan listrik, dan menikmati layanan tersebut. Pembayaran dilakukan bulanan sesuai pemakaian. Kalau listrik bisa seperti itu, mengapa layanan komputasi tidak bisa? Misalnya, apabila sebuah perusahaan membutuhkan aplikasi CRM (Customer Relationship Management). Kenapa perusahaan tersebut harus membeli aplikasi CRM, membeli hardware server, dan kemudian harus memiliki tim teknologi informasi khusus untuk menjaga server dan aplikasi tersebut? Struktur cloud computing dapat dilihat pada gambar 2 berikut.

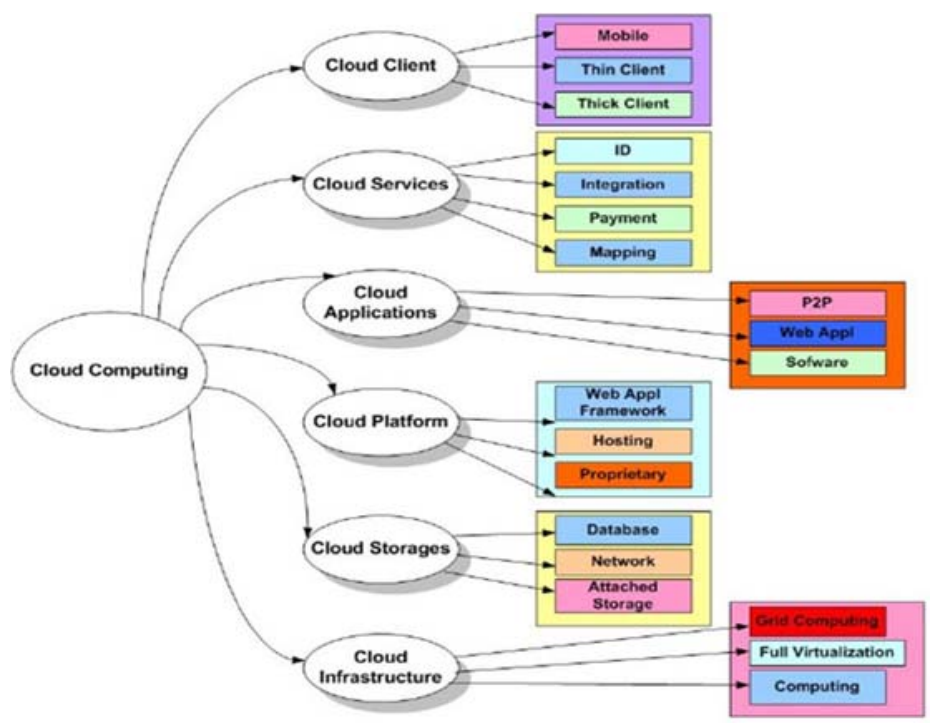

Gambar.2. Bagan Could computing didalam perusahaan 
Di sinilah cloud computing berperan. Penyedia jasa cloud computing seperti Microsoft, telah menyediakan aplikasi CRM yang dapat digunakan langsung oleh perusahaan tadi. Mereka tinggal menghubungi penyedia layanan (dalam hal ini, Microsoft), "menyambungkan" perusahaannya dengan layanan tersebut (dalam hal ini, melalui Internet), dan tinggal menggunakannya. Pembayaran? Cukup dibayar per bulan (atau per tahun, tergantung kontrak) sesuai pemakaian. Tidak ada lagi investasi di awal yang harus dilakukan.

Apakah contoh dari cloud computing? Jika Anda memiliki email dengan layanan web based email service seperti yang dimiliki Gmail, Yahoo, atau Hotmail, artinya Anda sudah masuk ke layanan cloud computing karena software dan media penyimpanannya tidaklah berada di komputer Anda, melainkan pada server mereka. Sebenarnya layanan cloud computing ini sudah ada cukup lama. Contohnya adalah Google Doc yang disediakan oleh Google. Disana Google menyediakan aplikasi sejenis 'microsoft office' dengan pengolah kata, pengolah presentasi, dan lainnya yang dapat digunakan saat Anda masuk ke situsnya. Dokumen yang dibuat tersebut dapat langsung disimpan di Google dan dapat dibuka kapanpun dan dimanapun. Dikatakan sebagai 'cloud' (= awan) karena aplikasi dan datanya berada pada cloud web server (Knorr, 2010). Sistem dari cloud computing dibagi menjadi 2 yaitu front end dan back end. Antara front end dan back end terkait satu sama lain melalui jaringan yang disebut Internet. Front end adalah bagian dimana pengguna komputer (user) atau client berada. Sedangkan back end adalah bagian dimana cloud dari sistem itu berada. Front end juga meliputi komputer client atau komputer jaringan dan aplikasi yang dibutuhkan untuk dapat mengakses sistem cloud computing. Sebagai ilustrasi dapat dilihat pada gambar 3 berikut:

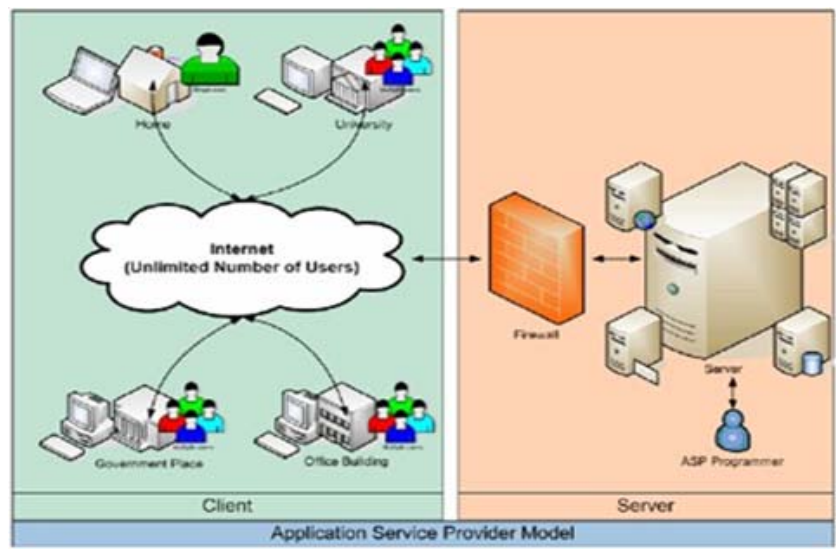

Gambar.3. Model ASP 
Tidak semua cloud computing memiliki user interface yang sama. Contohnya layanan seperti web browser dan layanan email antara satu dengan yang lain memiliki perbedaan akses yang dimiliki atau perbedaan interface. Pada sistem back end terdapat bermacam jenis komputer, server, dan sistem penyimpanan. Secara teori, sistem cloud computing bisa termasuk didalamnya bermacam program komputer mulai dari pemrosesan data hingga video game, dan biasanya setiap aplikasi memiliki server yang berbeda. Server pusat dari cloud computing akan mengatur sistem mulai dari memonitoring lalu lintas client dan permintaannya, dan menjamin semuanya berjalan dengan baik dan benar (Elsenpeter, 2010). Semuanya itu berjalan dengan sejumlah protokol dan menggunakan software khusus yang disebut middleware. Middleware inilah yang memungkinkan komputer pada jaringan dapat berkomunikasi satu dengan lainnya. Aplikasi yang terdapat pada cloud computing pada dasarnya tanpa batas. Dengan middleware yang tepat, sistem cloud computing dapat mengeksekusi semua program layaknya komputer biasa. Jadi, apapun yang biasa dilakukan pada sebuah PC atau laptop pasti dapat dikerjakan pada cloud computing.

Cloud computing tidak lama lagi akan menjadi realita, dan ini akan memaksa para IT professional untuk cepat mengadaptasi yang dimaksud dengan teknologi ini. Akibat dari keadaan sosial ekonomi yang terus mengalami revolusi yang sangat cepat sehingga melahirkan cloud computing, dimana teknologi ini dibutuhkan untuk kecepatan dan realibilitas yang lebih dari teknologi yang sebelumnya sehingga teknologi ini nantinya akan mencapai pada tingkat investasi dalam term cloud service yang cepat dan mudah.

\section{Tantangan Bisnis Era Teknologi Informasi}

\section{E-Commerce}

Internet saat ini sudah umum digunakan oleh dunia usaha dalam rangka mencari informasi dagang, promosi dagang, hubungan/kontrak dagang secara internasional ke seluruh Negara/dunia. Usaha yang menggunakan e-commerce yang dapat diakses menggunakan internet merupakan suatu usaha yang sangat unik, karena hanya dengan menggunakan satu media, peruahaan dapat melakukan usaha/bisnis, baik dengan sesama perusahaan (Business to Business - B2B) atau dapat proses bisnis langsung antara pebisnis dengan konsumen atau penjual dengan pembeli (Business to Consumer B2B). Mereka dapat melakukan proses bisnis, mulai dari promosi produk, penawaran, dan permintaan produk, tanya jawab antara konsumen dan produsen atau antara pembeli dengan penjual dapat dilakukan secara efektif dengan $e$ commerce (Assaraf, 2008). 
Model e-commerce seperti: Customer to Business (C2B), Business to Business (B2B), Customer to Customer (C2C) secara visual dapat dilihat pada gambar 4 berikut:

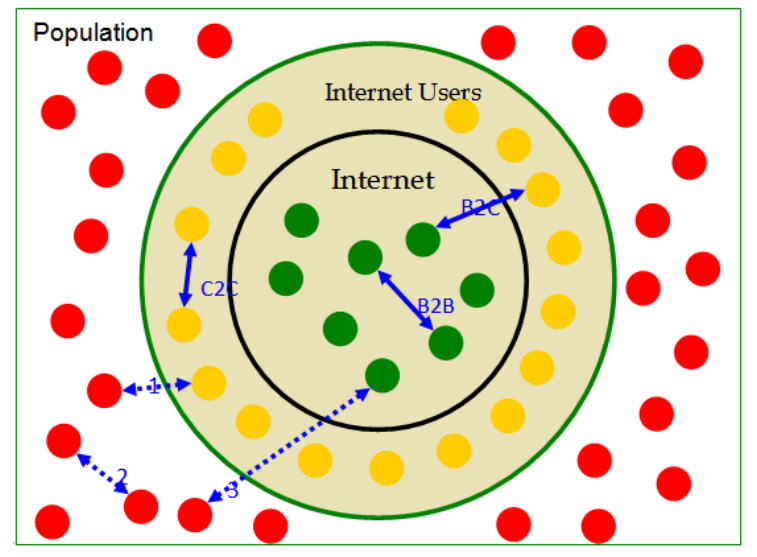

Gambar.4. Model e-commerce

Berdasarkan pada gambar tersebut, maka dapat dijelaskan sebagai berikut (Rhenald, 2007):

\section{Business to Business (B2B)}

B2B artinya proses bisnis antara penjual dengan penjual atau produsen dengan produsen atau produsen dengan grosir, pedagang, agen, dan sejenisnya dilakukan secara online. Mereka dapat melakukan proses bisnis, mulai dari promosi, penawaran dan permintaan produk, tanya jawab antara mereka dapat dilakukan dengan cara online melalui internet atau mobile phone yang memiliki fitur untuk itu. Tidak dapat dipungkiri bahwa kekuatan teknologi internet dan mobile semakin hebat. Teknologi pencarian informasi bisnis maupun informasi lainnya misal melalui situs Google.com. Google, yang notabenenya perusahaan pemasang iklan merupakan fenomena internet yang telah menjadi bagian dari kehidupan marketer dalam mencari informasi mulai dari produk atau jasa yang terbesar sampai yang terkecil, melihat dunia luar (contohnya Google Earth), mendengar (Google Alert), dan berkolaborasi dengan rekan sekantor (Google Docs, Gmail, Google Talk).

Tidak hanya merevolusi industri teknologi informasi, Google juga mengubah banyak tatanan industri mulai dari media (Google news, YouTube atau Google Video) sampai perpustakaan (Google Books, Google Schoolar). Google adalah internet, dan internet adalah Google. Dengan misinya yang sangat horizontal, yaitu "Mengelola Informasi Dunia dan Membuatnya Mudah diakses dan Berguna" Google 
telah menjadi bagian dari kehidupan masyarakat tulen dunia, New Wave yang ingin mencari, melacak, dan menggunakan sebuah informasi. Teknologi Web 1.0 adalah sudah mulai ditinggalkan, karena hanya dapat mencari, browsing, dan read-only. Kini dunia internet telah berubah. Teknologi internet masuk pada Web 2.0 telah membuat internet bersifat lebih interaktif dan dinamis. Interaksi dengan komunitas menjadi lebih memungkinkan karena pada dasarnya kekuatan sesungguhnya dari aplikasi internet yang bersifat Web. 2.0 adalah read and write. Internet dengan Web 2.0 membuat proses horizontal semakin cepat (Zimmerer, 1996).

Di dunia yang serba horizontal ini, berkat perkembangan teknologi internet, semua orang sekarang mempunyai kesempatan yang sama untuk terhubung, dihubungi, dan menghubungi. Kini eranya dimana kita dapat melihat sekaligus menyentuh, dan berinteraksi. Tidak hanya itu, dunia yang serba horizontal bukan hanya disebabkan oleh perkembangan teknologi semata. Pendorong nomor satu adalah perubahan teknologi dari yang bersifat one-to-many ke many-to-many. Perubahan teknologi ini mengundang datangnya berbagai tren lainnya. Berbagai tren yang ada, antara lain (Hukude, 2006):

1. From one-to-many broadcasting to many-to-many networking. Didorong oleh teknologi Web 2.0 menyebabkan membanjirnya aplikasi berbasis jejaring dari banyak ke banyak ini yang menyebabkan internet telah berubah. Trennya adalah read and write, mendorong orang lebih mengekspresikan dirinya, berpartisipasi, melakukan networking, membentuk komunitas lewat situs jejaring, dan banyak hal lainnya.

2. Form Ideology to Persona. Berkembangnya teknologi juga telah membuka dunia politik dan birokrasi lebih transparan. Sejak adanya internet, kita lebih dapat melihat gambaran politik secara nyata, sudah semakin susah untuk merahasiakan sesuatu. Sebagai contoh saat ini semakin banyak politis yang masuk di Facebook. Ketika profil Perdana Menteri China Wen Jiabao muncul di Facebook pada 14 Mei 2008, ia mendapat kawan sekitar 14.000 orang dalam waktu Cuma dua minggu, sedangkan profil Presiden Hu Jiantao waktu itu Cuma punya 1.000 pengikut. Ini bukti bahwa Wen lebih horizontal,meskipun keduanya adalah orang nomor satu dan dua China.

3. From $G 7$ to G20. Kelompok G (AS, Inggris Raya, Kanada, Prancis, Jerman, Italia, dan Jepang). Dalam sejarah perekonomian dunia era sebelum krisis, G7 tersebut secara rutin memakai peran konstruktif dalam mengoordinasikan kebijakan global mengenai perekonomian dunia. Artinya, secara vertikal mendikte Negara-negara lain, termasuk Negara-negara berkembang. Saat ini telah berubah, Kelompok G7 telah secara perlahan memudar. Mereka tidak lagi merepresentasikan wajah perekonomian dunia sebagaimana yang 
diperlihatkan oleh G20, yaitu kelompok 20 negara perekonomian besar dunia yang menghimpun hampir $90 \%$ GNP dunia, $80 \%$ total perdagangan dunia dan dua per tiga penduduk dunia. Dalam kondisi perekonomian global seperti sekarang,kelompok G7 tampil lebih horizontal, menunjukkan sikap kompromi, dan kolaboratif dengan negara-negara berkembang. Semakin kompetitifnya Negara-negara berkembang terutama China dan India, permasalahan dunia global harus diselesaikan bersama-sama secara horizontal melalui G20.

4. From Belief to Humanity. Dalam era teknologi informasi dan komunikasi, kita semua saling terjaring dalam dunia sosial dan budaya yang baru yang lebih humanis. Contoh di dunia maya, membuktikan bahwa agama yang bersifat vertikal dapat hidup berdampingan dengan aspek kemanusiaan dan sosialbudaya yang bersifat horizontal. Teknologi yang kita gunakan saat ini dapat menjelajah dunia dan membuka cakrawala baru di mana tiap-tiap manusia semakin dan tidak berarti.

5. From Close to Open Market. Keempat tren baru tersebut di atas, menurut Hermawan Kertajaya membawa angin baru ke market yang berubah dari relatif tertutup ke relatif lebih terbuka. Pasar global telah menjadi daftar dan semua marketer memiliki kesempatan yang sama. Dengan adanya kemajuan platform teknologi online dan mobile, pengusaha/penjual dapat menjangkau pembeli tanpa batas, di sisi lain, pembeli dapat keleluasaan untuk memilih berbagai penawaran dari manapun untuk mendapatkan barang dan atau jasa dengan value yang baik. Platform yang memfasilitasi transaksi antara pengusaha atau penjual dan pembeli yang sifatnya Customer-to-Customer (C2C), seperti eBay, Alibaba, dan Kasus di dunia online merupakan contoh konkret bahwa era New Wave, pasar semakin horizontal.

6. From Competition to Co-operative. Perkembangan teknologi terkini tengah mengubah semua yang ada di lingkungan bisnis, mulai dari lingkungan mikro hingga makro. Di tengah pasar yang semakin terbuka, persaingan yang semakin menyimpan segudang peluang juga tantangan sendiri bagi pemasar. Untungnya di era sekarang, dunia semakin transparan, dan akses informasi semakin mudah dan cepat. Kita dapat mengetahui kelemahan dan kekuatan para kompetitor kita dan dapat mengakses ke konsumen mereka, celakanya, kompetitor juga memiliki akses yang sama terhadap kekuatan dan kelemahan kita, dan konsumen kita. Di era New Wave ini, persaingan yang sehat terjadi ketika bidang permainannya sama besar. Semua pemain berada pada posisi yang sejajar, tidak ada yang lebih tinggi atau lebih rendah. Kita dapat menang bila kita lebih unggul, sebaliknya dapat kalah bilakita tidak memiliki keunggulan, bukan karena menjelek-jelekkan kompetitor atau bermain licik dan kasar. 
Kunci untuk meredam munculnya permainan kasar dari kompetitor, pada akhirnya ditentukan oleh siapa yang mau berkolaborasi secara adil (fair) dengan para kompetitor. Tren yang disebut co-operation ini menjadi contoh di era New Wave, bagaimanapun pemasar harus semakin mengorizontalkan diri dengan para kompetitor potensialnya.

7. The Rise of New Customer: Digital Native. Salah satu dari tiga konsumen baru yang terus berkembang adalah masyarakat tulen New Wave yang dinamakan Digital Native alias konsumen yang asli digital. Konsumen yang well-connected dengan dunia digital. Konsumen seperti ini sifatnya transendental (di luar pengertian dan pengalaman manusia biasa) tidak terkotakkotakkan secara umur, demografis, geografis, strata sosial dan status lainnya. Benang merah dari konsumen baru ini adalah merasa "hidup" 24 jam secara horizontal di planet New Wave. Sudah saatnya tiap pemasar untuk mengenali mereka, mengetahui perilaku mereka, dan mengenali kegelisahan zaman ini atau keinginan (anxiety and desire) yang mereka miliki.

8. The Rise or New Customer: New Emergig Youth. Konsumen baru kedua adalah "New Emerging Youth atau konsumen baru berumur delapan hingga dua puluh empat tahun yang merupakan generasi muda atau baru di era millenium. Merekalah yang memegang peranan berikutnya di sektor ekonomi, setelah punahnya generasi baby-boomer dan semakin menuanya generasi $\mathrm{X}$. Beranjak dewasa dengan berbagai alat teknologi informasi dan komunikasi, secara otomatis paradigma mereka menjadi sangat New Wave dan serba horizontal. Sudah menjadi keharusan tersendiri bagi para New Wave Marketer untuk mengenali, memahami, dan menghampiri mereka secara horizontal.

9. The Rise of New Customer: "New Urban Woman". Konsumen ketiga pada era New Wave kaum wanita urban yang secara metafora atau kiasan datang dari planet venus, tetapi kini telah migrasi ke planet New Wave. Kaum wanita secara alami dipandang sebagai pembawa gerakan horizontal, terutama karena isu-isu seputar perbedaan gender yang dicatat dalam sejarah. Dengan kecanggihan alat teknologi informasi dan komunikasi saat ini, kekuatan wanita dalam melakukan word of mouth (dari mulut ke mulut) dan word of mouse menjadi lebih besar. Mereka yang dapat mengajari para New Wave Marketer bagaimana menjadi pemasar yang lebih menunjukkan sisi emosional dan humanism.

10. The Connector. Menghubungkan para pemasar dengan lingkunan bisnisnya, competitor, konsumen, dan para change agents (agen pembaruan) yang aktif membentuk perubahan tatanan makro mulai dari perubahan teknologi, politik dan legal, ekonomi, sosial budaya, dan pasar. Konektor terdiri atas tiga jenis, 
yaitu mobile interaction, experiental events, dan social media ada di belahan dunia online dan offline. Dengan adanya konektor, pemasar di era New Wave dapat menerapkan apa yang dinamakan Always-on-Connection. Setiap waktu (detik) telah terjadi koneksi yang menghubungkan perusahaan (company) dengan 3C lainnya, yaitu Change Agents, Competitor, dan Customer. Tanpa konektor, pemasaran harus bersiap-siap menanti ajal.

Dari berbagai tren tersebut di atas dapat disimpulkan bahwa dengan teknologi internet dan mobile communication yang mengalami perubahan begitu cepat, setiap pengusaha dituntut untuk mampu memanfaatkan berbagai peluang bisnis yang begitu terbuka, transparan, cepat, sehingga pengusaha dituntut jangan sampai ketinggalan zaman atau gagap teknologi. Dalam artikel ini,B2B tidak dibahas secara detail, tetapi yang akan dibahas agak relatif lebih luas adalah B2C berikut (Masasya, 2009).

\section{Business to Customer (B2C)}

Business to customer (B2C) merupakan bagian dari e-commerce yang biasanya merupakan sarana yang digunakan untuk bertransaksi atau proses bisnis atau melakukan aktivitas jual beli secara online, misalnya untuk mengetahui jumlah produk yang ada di pasar, atau melakukan proses jual beli barang secara langsung. B2C merupakan salah satu model e-commerce yang muncul untuk membantu suatu perusahaan dan konsumen dapat melakukan transaksi secara elektronik atau online di mana dan kapan saja. B2C mengubah cara atau proses berbelanja dan lebih berfokus pada ajakan penjual kepada pembeli untuk melakukan tawar-menawar dalam proses online atau proses jual beli secara tidak langsung.

Berbagai layanan yang dapat diberikan oleh B2C, antara lain: (1) memuat sampel produk yang akan dijual beserta informasi penting lainnya di internet atau dunia maya; (2) transaksi pemesanan barang secara online; (3) transaksi pembayaran barang; (4) transaksi pengiriman barang; (5) memuat berbagai informasi mutakhir berbagai produk dan atau jasa; dan (6) memberikan layanan servis lengkap secara online. Secara garis besar tipe-tipe pelayanan B2C terbagi menjadi 3 bentuk, yaitu (Hisrich, 1998):

a. Auction stores. Toko lelang internet sebagai tempat untuk memberikan pelayanan dalam bidang perdagangan, misalnya untuk menghasilkan produk perusahaan, cara pembayaran dan sebagainya, sehingga dapat diketahui juga jika menggunakan pelayanan Anda dapat memaksimalkan keuntungan yang ingin dicapai karena penawaran yang sangat banyak dari berbagai Negara. Keuntungan dari auction store: 
1. Convenience. Seseorang dapat tetap tinggal di rumah atau kantor, tetap dapat berpartisipasi dalam perdagangan atau melakukan tawar-menawar.

2. Flexibility. Dengan layanan ini dapat menyinkronisasi tawar-menawar antara penawar dan pelanggan bukan hanya untuk waktu saat itu saja, tetapi dapat mengetahui proses beberapa waktu lampau.

3. Increased reach. Layanan internat auction ini dapat memperluas daerah jangkauan, sehingga tentunya mampu meningkatkan keuntungan, karena penawaran dapat menjangkau ke pelosok dunia manapun.

4. Economical to operate. Dengan menggunakan layanan ini makin memperkecil biaya untuk pengembangan yang dibutuhkan.

5. Inspection of goods. Tidak dapat memungkinkan seseorang untuk melakukan pemeriksaan barang secara fisik yang akan dibelinya.

6. Potential for fraud. Dapat memungkinkan terjadinya penipuan karena proses pembayaran dan pengiriman barang yang cenderung tidak dilakukan secara bersama, sehingga memungkinkan penjual telah mengirim barang, namun pembayaran masih belum dapat diselesaikan bersama pengiriman barang.

b. Online Stores. Layanan ini merupakan tempat untuk menjual atau membeli barang secara digital dengan memilih dan memesan barang dengan menggunakan internet tanpa harus bertatap muka secara langsung dengan penjual maupun yang ingin dibeli, contoh situs www.amazon.com. Keuntungan online stores bagi perusahaan dan industri: (1) increased demand, bertambah banyaknya permintaan; (2) low cost route to globe reach lini biaya yang rendah menuju pencapaian dunia atau pencapaian global; (3) cost reduction of promotion and sales, penurunan biaya promosi dan biaya penjualan; dan (4) reduced cost, pengurangan biaya. Keuntungan online stores bagi konsumen: (1) lower price, harga relatif lebih murah;(2) wider choice, pilihan yang lebih luas; (3) better information, informasi yang lebih baik; dan (4) convenience, praktis atau menyenangkan.

c. Online Services. Layanan ini merupakan tempat untuk meminta informasi atau servis lain dari perusahaan dengan cepat dan mudah atau dapat melakukan proses jual beli jasa misalnya tiket perjalanan, jasa servis, dan lain-lain, contoh, situs www.travelcity.com. Berbagai kemampuan yang dimiliki dengan menggunakan layanan internet dengan model online service antara lain: (1) instantaneous communications, komunikasi yang segera atau seketika; (2) global access, akses global atau seluruh dunia; (3) customization, pembiasaan; (4) increased availability, tersedianya peningkatan; (5) deintermediation-de-intermediasi atau perantara-penengah; (6) consolidation 
and convergence, konsolidasi dan bersatu di suatu tempat; dan (7) colaboration, kolaborasi atau kerja sama.

\section{Karakteristik Cloud Computing dalam Pemasaran}

Bahwa tidak semua aplikasi berbasis web dapat dimasukkan ke dalam kategori cloud computing. Ada lima kriteria yang harus dipenuhi oleh sebuah sistem untuk bisa dimasukkan dalam keluarga Cloud Computing, yaitu (Raffaell, 2010):

a. Swalayan (On Demand Self Service). Seorang pelanggan dimungkinkan untuk secara langsung "memesan" sumber daya yang dibutuhkan, seperti processor time dan kapasitas penyimpanan melalui control panel elektronis yang disediakan. Jadi tidak perlu berinteraksi dengan personil customer service jika perlu menambah atau mengurangi sumberdaya komputasi yang diperlukan.

b. Akses Pita Lebar (Broadband Network Access). Layanan yang tersedia terhubung melalui jaringan pita lebar, terutama untuk dapat diakses secara memadai melalui jaringan internet, baik menggunakan thin client, thick client ataupun media lain seperti smartphone.

c. Sumberdaya Terkelompok (Resource Pooling). Penyedia layanan cloud, memberikan layanan melalui sumberdaya yang dikelompokkan pada satu atau berbagai lokasi data center yang terdiri dari sejumlah server dengan mekanisme multi-tenant. Mekanisme multi-tenant ini memungkinkan sejumlah sumberdaya komputasi tersebut digunakan secara bersama-sama oleh sejumlah user, di mana sumberdaya tersebut baik yang berbentuk fisik maupun virtual, dapat dialokasikan secara dinamis untuk kebutuhan pengguna/ pelanggan sesuai permintaan. Dengan demikian, pelanggan tidak perlu tahu bagaimana dan darimana permintaan akan sumberdaya komputasinya dipenuhi oleh penyedia layanan. Yang penting, setiap permintaan dapat dipenuhi. Sumberdaya komputasi ini meliputi media penyimpanan, memory, processor, dan pita jaringan.

d. Elastis (Rapid Elasticity). Kapasitas komputasi yang disediakan dapat secara elastis dan cepat disediakan, baik itu dalam bentuk penambahan ataupun pengurangan kapasitas yang diperlukan. Untuk pelanggan sendiri, dengan kemampuan ini seolah-olah kapasitas yang tersedia tak terbatas besarnya, dan dapat "dibeli" kapan saja dengan jumlah berapa saja. 
e. Layanan Yang Terukur (Measured Service). Sumber daya cloud yang tersedia harus dapat diatur dan dioptimasi penggunaannya, dengan suatu sistem pengukuran yang dapat mengukur penggunaan dari setiap sumberdaya komputasi yang digunakan (penyimpanan, memory, processor, lebar pita, aktivitas user, dan lainnya). Dengan demikian, jumlah sumberdaya yang digunakan dapat secara transparan diukur yang akan menjadi dasar bagi user untuk membayar biaya penggunaan layanan.

\section{Kelebihan Cloud Computing dalam Bisnis}

Keuntungan dari penggunaan cloud computing ini sangat banyak. Mulai dari kemudahan akses dimana aplikasi dan data dapat diakses kapanpun dan dimanapun. Demikian juga untuk urusan penghematan. Pengguna tidak perlu memikirkan untuk membeli sebuah komputer terbaru dengan memori yang besar beserta berbagai software pendukung. Di masa yang akan datang semua disediakan pada cloud computing. Bila cloud computing ini dikerjakan atau diakses pada sebuah perangkat portabel seperti smartphone atau tablet yang dapat mengakses Internet via WiFi, bayangkan kemudahan yang dapat diperoleh.

Salah satu kelebihan cloud computing adalah sangat cepat di deploy, sehingga cepat berarti instant untuk implementasi. Menurut Furht, Borko dan Escalante (2010) kelebihan cloud computing adalah: (1) nantinya biaya start-up teknologi ini akan sangat murah atau tidak ada dan juga tidak ada investasi kapital; (2) biaya dari service dan pemakaian akan berdasarkan komitmen yang tidak fix; (3) service ini dapat dengan mudah di upgrade atau downgrade dengan cepat tanpa adanya penalty; (4) service ini akan menggunakan metode multi-tenant (banyak customer dalam 1 platform); dan (5) kemampuan untuk meng customize service akan menjadi terbatas.

Tetapi, cloud computing juga memiliki resiko, diantaranya (Mell and Grance, 2009): (1) Service level-Cloud provider mungkin tidak akan konsisten dengan performance dari application atau transaksi. Hal ini mengharuskan pebisnis untuk memahami service level yang didapatkan mengenai transaction response time, data protection dan kecepatan data recovery. (2) Privacy-karena orang lain/ perusahaan lain juga melakukan hosting kemungkinan data perusahaan akan keluar atau di baca oleh orang lain dapat terjadi tanpa sepengetahuan pemilik atau approve dari perusahaan bersangkutan.(3) Data ownership-kepemilikan data yang diberikan akan menjadi dapat menjadi milik bersama di dunia maya.

Mungkin yang masih menjadi persoalan terbesar cloud computing adalah tentang keamanan dan privasi. Pencurian data (hack/crack) oleh pihak lain membuat khawatir sebagian orang. Apalagi bila sebuah perusahaan besar yang memiliki data 
atau rahasia penting kemungkinan masih berfikir panjang sebelum mau memanfaatkan cloud computing ini. Secara lengkap kelebihan cloud computing adalah sebagai berikut (Hartig, 2008):

1. Tanpa Investasi Awal. Dengan cloud computing, pebisnis dapat menggunakan sebuah layanan tanpa investasi yang signifikan di awal.Ini sangat penting bagi bisnis, terutama bisnis pemula (startup). Mungkin di awal bisnis, pebisnis hanya perlu layanan CRM untuk 2 pengguna. Kemudian meningkat menjadi 10 pengguna. Tanpa model cloud computing, maka sejak awal pebisnis sudah harus membeli hardware yang cukup untuk sekian tahun ke depan. Dengan cloud computing, pebisnis cukup membayar sesuai yang dibutuhkan.

2. Mengubah CAPEX menjadi OPEX. Tanpa cloud computing, investasi hardware dan software harus dilakukan di awal, sehingga pebisnis harus melakukan pengeluaran modal (Capital Expenditure, atau CAPEX). Sedangkan dengan cloud computing, pebisnis dapat melakukan pengeluaran operasional (Operational Expenditure, atau OPEX). Jadi, sama persis dengan biaya utilitas lainnya seperti listrik atau telepon ketika membayar bulanan sesuai pemakaian. Hal ini akan sangat membantu perusahaan secara keuangan.

3. Lentur dan Mudah Dikembangkan. Dengan memanfaatkan cloud computing, pebisnis dapat memanfaatkan teknologi informasi sesuai kebutuhan. Gambar di bawah adalah contoh beberapa skenario kebutuhan bisnis. Penggunaan teknologi informasi secara bisnis biasanya tidak datardatar saja. Dalam skenario predictable bursting, ada periode di mana penggunaan TI meningkat tajam. Contoh mudah adalah aplikasi Human Resource (HR) yang pada akhir bulan selalu meningkat penggunaannya karena mengelola gaji karyawan. Untuk skenario growing fast, bisnis meningkat dengan pesat sehingga kapasitas teknologi informasi juga harus mengikuti. Contoh scenario Unpredictable Bursting adalah ketika sebuah website berita mendapat pengunjung yang melonjak karena ada berita menarik. Skenario On and $O f f$ adalah penggunaan teknologi informasi yang tidak berkelanjutan . Misalnya, sebuah layanan pelaporan pajak, yang hanya digunakan di waktuwaktu tertentu setiap tahun sebagaimana pada gambar 5 berikut (Hayes, 2008): 

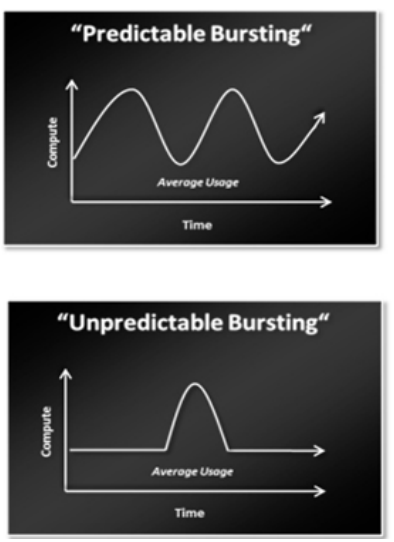
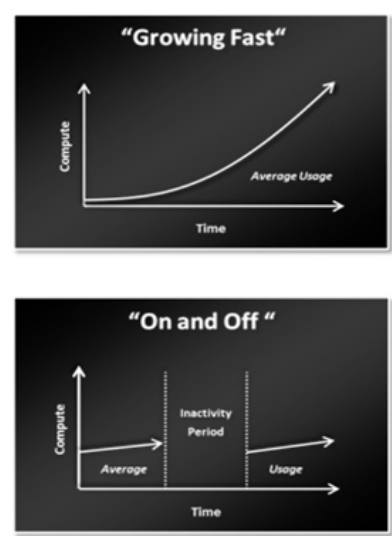

Gambar.5. Contoh scenario Unpredictable Bursting

Tanpa layanan cloud computing, ke empat skenario ini akan membutuhkan perencanaan teknologi informasi yang sangat tidak efisien, karena investasi teknologi informasi harus dilakukan sesuai kapasitas tertinggi, walaupun mungkin hanya terjadi di saat-saat tertentu. Hal ini dilakukan untuk mencegah terjadinya kegagalan layanan pada saat peak time tersebut. Dengan cloud computing, karena sifatnya yang lentur dan mudah dikembangkan (elastic and scalable), maka kapasitasnya dapat ditingkatkan pada saat dibutuhkan, dengan biaya penggunaan sesuai pemakaian.

4. Fokus pada Bisnis, bukan teknologi informasi. Dengan menggunakan cloud computing, pebisnis dapat fokus pada bisnis utama perusahaan, dan bukan berkecimpung di dalam pengelolaan teknologi informasi. Hal ini dapat dilakukan karena pengelolaan teknologi informasi dilakukan oleh penyedia layanan, dan bukan oleh diri sendiri. Misalnya, melakukan patching, security update, upgrade hardware, upgrade software, maintenance, dan lainlain.

\section{Layanan Cloud Computing dalam Bisnis}

Implikasi dari komputasi awan ini boleh dikatakan sudah sangat luas dan besar. Dengan konsep independensi dan skala horisontal yang bisa dicapai maka lahirlah istilah-istilah baru layanan seperti Sofware as a Service (SaaS) dan Platform as a Service. Para vendor ternama dan yang baru bermunculan di bidang solusi teknologi informasi sudah mulai berlomba-lomba menyediakan hosting layanan 
seperti ini. Produk yang disediakan juga sangat beragam baik dari sisi fungsionalitas maupun skema layanan apakah gratis atau berbayar. Ada tipe layanan yang sangat sederhana, bahkan bisa langsung disisipkan ke situs kita dengan kode XML tanpa coding sama sekali seperti layanan Google Friend Connect. Ada juga yang mengharuskan kita ke situs vendor terkait untuk menggunakan layanan mereka (ISACA, 2009).

Berikut beberapa produk layanan yang berhubungan dengan bisnis dan produktivitas, disediakan oleh vendor-vendor ternama maupun yang baru bermunculan: (1) microsoft office live (http://smallbusiness.officelive.com); (2) google docs (http://docs.google.com); dan (3) Vertica Analytical Database. Dan berikut beberapa produk platform pengembangan aplikasi yang khusus ditujukan kepada para programmer/developer, antara lain adalah: (1) Google App Engine; (2) GData API for Google Product Platform; (3) Amazon Elastic Compute Cloud (EC2); (2) Microsof Live Mesh; dan (3) Snaplogic untuk integrasi data. Sebagai gambaran dapat dilihat pada gambar 6 berikut (Mark-Shane, 2009):

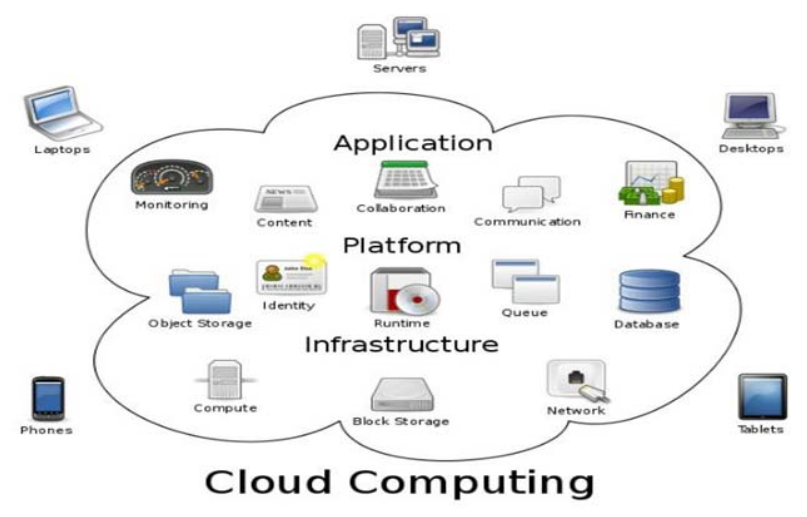

Gambar.6. layanan cloud computing

Berdasarkan gambar di atas, berikut dibahas tiga layanan cloud computing dalam bisnis dan pemasaran.

\section{a. Software as a Service (SaaS)}

Sebagai konsumen individual, pebisnis sebenarnya sudah akrab dengan layanan cloud computing melalui Yahoo Mail, Hotmail, Google Search, Bing, atau MSN Messenger. Contoh lain yang cukup populer adalah Google Docs ataupun Microsoft Office Web Applications yang merupakan aplikasi pengolah dokumen berbasis internet. Di dunia bisnis, pebisnis mungkin familiar dengan SalesForce.com atau Microsoft CRM yang merupakan layanan aplikasi CRM. Di sini, perusahaan 
tidak perlu setup hardware dan software CRM di server sendiri. Cukup berlangganan SalesForce.com maupun Microsoft CRM, pebisnis bisa menggunakan aplikasi CRM kapan dan dari mana saja melalui internet. Pebisnis tidak perlu melakukan investasi server maupun aplikasi. Pebisnis juga akan selalu mendapat aplikasi terbaru jika terjadi upgrade (Robert Elsenpeter, 2010).

Intinya, pebisnis benar-benar hanya tinggal menggunakan aplikasi tersebut. Pembayaran biasanya dilakukan bulanan, dan sesuai jumlah pemakai aplikasi tersebut. Dengan kata lain, pay as you go, pay per use, per seat. Semua layanan ini, dimana suatu aplikasi software tersedia dan bisa langsung dipakai oleh seorang pengguna, termasuk ke dalam kategori Software as a Service (SaaS). Secara sederhana, pebisnis langsung mengkonsumsi layanan aplikasi yang ditawarkan.

\section{b. Platform as a Service (PaaS)}

Sering terjadi, suatu aplikasi software yang sifatnya package tidak dapat memenuhi kebutuhan proses bisnis. Demikian pula dengan SaaS, di mana aplikasi yang ditawarkan sebagai layanan tidak sesuai dengan proses bisnis yang diinginkan. Pada skenario ini, pebisnis dapat menggunakan jenis layanan yang disebut Platform as a Service (PaaS). Pada PaaS, pebisnis membuat sendiri aplikasi software yang diinginkan, termasuk skema database yang diperlukan. Skema itu kemudian dipasang (deploy) di server-erver milik penyedia jasa PaaS. Penyedia jasa PaaS sendiri menyediakan layanan berupa platform, mulai dari mengatur server-server mereka secara virtualisasi sehingga sudah menjadi cluster sampai menyediakan sistem operasi di atasnya. Hasilnya, pebisnis sebagai pengguna hanya perlu memasang aplikasi yang dibuat di atasnya. Hal ini dapat diskemakan pada gambar 7 berikut (MarkShane dan E. Scale, 2009).

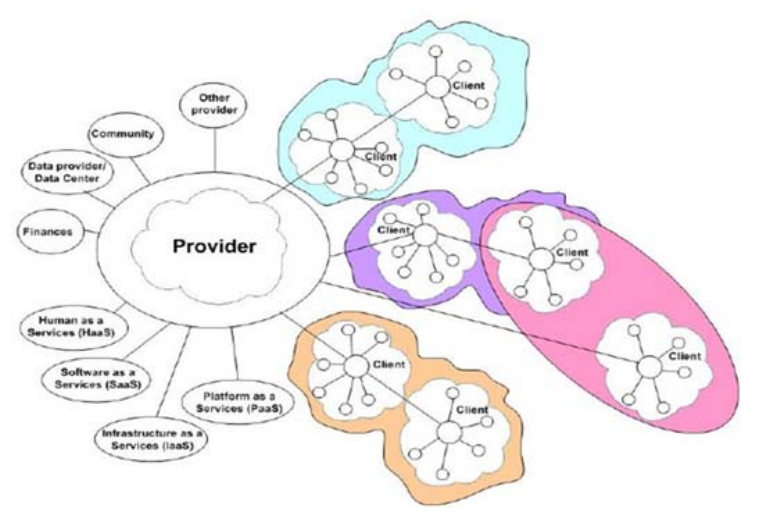

Gambar.7. Skema database 
Pada perusahaan pembuat software, PaaS juga memberi alternatif lain. Alihalih memasang software di server konsumen, pebisnis bisa memasang software tersebut di server milik penyedia layanan PaaS, kemudian menjualnya ke konsumen dalam bentuk langganan. Dengan kata lain, perusahaan membuat sebuah SaaS. Singkatnya, dengan PaaS, perusahaan membangun aplikasi sendiri di atas layanan PaaS tersebut. Adapun contoh vendor penyedia layanan Paas adalah Microsoft Azure dan Amazon Web Services.

\section{c. Infrastructure as a Service (IaaS)}

Ada kasus ketika konfigurasi yang disediakan oleh penyedia PaaS tidak sesuai dengan keinginan perusahaan. Pebisnis berniat menggunakan aplikasi yang memerlukan konfigurasi server yang unik dan tidak dapat dipenuhi oleh penyedia PaaS. Untuk keperluan seperti ini, pebisnis dapat menggunakan layanan cloud computing tipe Infrastructure as a Service (IaaS). Pada IaaS, penyedia layanan hanya menyediakan sumber daya komputasi seperti prosesor, memori, dan storage yang sudah tervirtualisasi. Akan tetapi, penyedia layanan tidak memasang sistem operasi maupun aplikasi di atasnya. Pemilihan operating sistem, aplikasi, maupun konfigurasi lainnya sepenuhnya berada pada kendali perusahaan. Jadi, layanan IaaS dapat dilihat sebagai proses migrasi server-server pemasar dari on-premise ke data center millik penyedia IaaS ini. Para vendor cloud computing lokal rata-rata menyediakan layanan model IaaS ini, dalam bentuk Virtual Private Server.

Perbedaan SaaS, PaaS dan IaaS dapat dilihat dari sisi kendali atau tanggung jawab yang dilakukan oleh vendor penyedia jasa layanan cloud maupun customer. Pada gambar di bawah, dijelaskan stack (jenjang) teknologi komputasi dari Networking naik hingga ke Application. Di situ juga dijelaskan sampai di stack mana suatu vendor layanan cloud memberikan layanannya, dan mulai dari jenjang mana konsumen mulai memegang kendali dan bertanggung jawab penuh pada stack di atasnya. Sebagai ilustrasi dapat dilihat pada gambar 8 berikut.

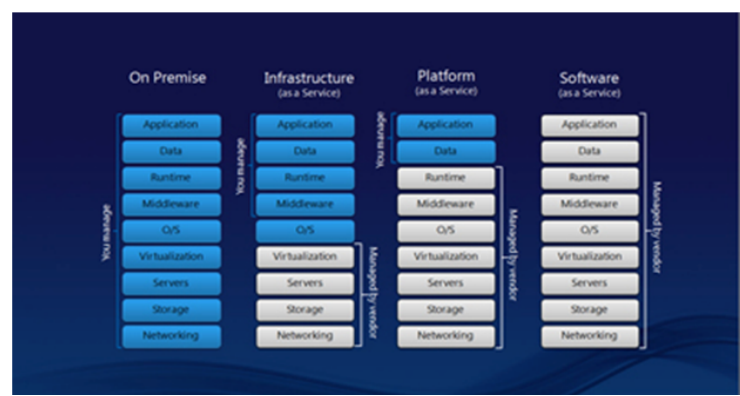

Gambar.8. Skema kendali dan tanggung jawab layanan 
Mulai dari kanan, pada SaaS, seluruh stack merupakan tanggung jawab penyedia layanan cloud. Konsumen benar-benar hanya mengkonsumsi aplikasi yang disediakan. Pada PaaS, penyedia layanan cloud bertanggung jawab mengelola Networking hingga Runtime. Konsumen memiliki kendali dan bertanggung jawab membuat aplikasi dan juga skema database-nya. Pada IaaS, penyedia layanan cloud bertanggung jawab untuk Networking hingga Virtualization. Konsumen sudah mulai bertanggung jawab untuk operating system ke atas. Sebagai perbandingan, di gambar juga ditunjukkan arsitektur tradisional on-premise (bukan cloud), alias semua ada di data center perusahaan. Di sini pebisnis bertanggung jawab untuk seluruh stack, dari Networking hingga Application.

\section{KESIMPULAN}

Cloud computing sudah hadir saat ini, termasuk di Indonesia. Jadi, cloud computing bukanlah sebuah hype, melainkan sudah menjadi kenyataan dalam dunia teknologi informasi.

Bukan berarti pebisnis dan pemasar langsung harus berpindah saat ini juga: pada kenyataannya cloud computing bukanlah untuk semua orang. Masih tetap terdapat jenis-jenis layanan yang harus dilakukan secara on-premise, walaupun terdapat juga layanan yang menjadi sangat efisien bila dilakukan dengan cloud computing. Beberapa jenis layanan bahkan dapat dilakukan secara bersamaan (hybrid) dengan menggabungkan kedua jenis implementasi tersebut.

Secara umum arsitektur komputasi awan terdiri dari: (1) Infrastructure as a Service (IaaS); (2) Platform as a Service (PaaS); dan (3) Software as a Service (SaaS). Karakteristik cloud computing adalah: (1) swalayan (on demand self service); (2) akses pita lebar (broadband network access); (3) sumberdaya terkelompok (resource pooling); (4) elastis (rapid elasticity); dan (5) layanan yang terukur (measured service). Sedangkan yang menjadi kelebihan cloud computing adalah: (1) tanpa investasi awal; (2) mengubah CAPEX menjadi OPEX; (3) lentur dan mudah dikembangkan; (4) fokus pada bisnis, bukan teknologi informasi; dan (5) kendali dan tanggungjawab pelayanan. Dengan cloud computing konsumen membebaskan diri dari tanggung jawab untuk mengelola stack sumber daya komputasi.Levelnya mulai dari SaaS ketika benar-benar bebas, PaaS ketika masih harus membuat aplikasi, dan IaaS yang masih sibuk dengan operating system. Ini berbeda dengan On-Premise yang harus mengurus semua sendiri. 


\section{DAFTAR PUSTAKA}

1. Assaraf, J, Smith, M, 2008, The Answer: Mencapai Sukses Bisnis, Meraih Kebebasan Finansial dan Memiliki Hidup Berkelimpahan, Terjemahan Susi Purwoko, Gramedia: Jakarta.

2. Ercana, Tuncay, 2010. Effective Use of Cloud Computing in Educational Institutions. Procedia Social and Behavioral Sciences 2 (2010): p. 938942.

3. Elsenpeter, Robert, 2010. Cloud Computing: A Practical Approach. New York: McGraw-Hill International.

4. Furht, Borko dan Armando Escalante, 2010. Handbook of Cloud Computing. Springer: New York.

5. Hartig, K. 2008. What is Cloud Computing? Cloud Computing Journal available at: http://cloudcomputing. sys-con.com/node/579826, diakses 4 Desember 2011.

6. Hayes, B. 2008. Cloud Computing. Communications of the ACM, 51 (7), p. 9-11.

7. Hisrich, Robert D dan Michael P. Peter, 1998, Entrepreneurship, Boston, MA : Irwin International, Inc.

8. Hukude Gail P, 2006, Small Business on Entrepreneurs Business Plan, Internasional Edition, Thomson Higher Education: Ohio.

9. ISACA. 2009. Cloud Computing: Business Benefits With Security, Governance and Assurance Perspectives. :http://www.isaca.org / Knowledge Center /Research /Documents/Cloud-Computing-28Oct09Research.pdf, diakses 2 Desember 2011.

10. Knorr, Eric dan Galen Gruman, 2010. What cloud computing really means, InfoWorld, www.infoworld.com/d/cloud-computing/what-cloud-computingreally-means-031, diakses 6 Desember 2011.

11. Mark-Shane E. Scale, 2009. Cloud Computing and Collaboration. Library Hi Tech News, Vol. 26: 9, pp. 10-13.

12. Mell, P and Grance T, 2009. Presentation on Effectively and Securely Using the Cloud Computing Paradigm. :http://csrc.nist.gov/groups/SNS/ cloud computing/cloud- computing, diakses 2 Desember 2011.

13. Masasya, Elvyn G Irianto, 2007, 25 Rahasia: Mengelola Usaha Di Era Turbulensi, Rinto Hendro: Jakarta.

14. Okuhara, Shiozaki, 2010. Security Architecture for Cloud Computing. FUJITSU Sci. Tech. J. v.46(4) : p. 397-402 :http://www.fujitsu. com/ downloads/MAG/vol46-4/, diakses 1 Desember 2011. 
15. Raffaell, 2010. Teknologi Cloud Computing (Sebuah Pendekatan), Teknoinfo,teknoinfo.web.id/teknologi-cloud-computing/, diakses 5 Desember 2011.

16. Rhenald Kasali, 2007, Re-Code Your Change DNA, Gramedia Pustaka Utama: Jakarta.

17. Turban, E. Aronson J.E, Peng Liang, 2005, Decision Support Systems and Intelligent Systems: Sistem Pendukung Keputusan dan Sistem Cerdas, Terjemahan Dwi Prabontini, Andi: Jogyakarta.

18. Velte, Anthony T., Toby J. Velte \& Robert Elsenpeter, 2010. Cloud Computing: A Practical Approach. New York: McGraw-Hill International.

19. Zimmerer, W, Thomas, Norman, M. Scarborough, 1996, Entrepreneurship and the New Venture Formation, Prentice Hall Inc: New Jersey. 